\title{
Choice of Credit Facilities: A Stimulant for Financial Performance of SMEs In Nigeria
}

\author{
Modupe Olayinka Ajayi, (Ph.D) \\ Department of Project Management Technology, \\ Federal University of Technology Akure, Ondo-State
}

\begin{abstract}
The study examined the effects of choice of credit facilities on the financial performance of SMEs in Nigeria while the specific objectives are to establish the influence of interest rate on loan and service on performance of registered SMEs in Ekiti State; investigate the influence of trade credits on performance of registered SMEs in Ekiti and examine the effect of asset financing on performance of registered SMEs in Ekiti State. The population of the study comprised 1704 SMEs operators from 16 local government areas in Ekiti State Nigeria. The stratified sampling technique was used to select the sample size from the captive population. The total sample size is 324 SMEs. This is the minimum to go to field with. $10 \%$ of 324 were added to the sample size, summing up to give 356 because of non-response rate. To achieve the set objectives and hypotheses, both descriptive and inferential statistics were employed. In the descriptive analysis, the use of percentages comes to bare; more importantly in the areas of frequency of respondents to their views on the questions of research instrument. In specific terms, to achieve the objectives ANCOVA analysis were adopted. The results revealed that interest loan and performance between the groups revealed that a statistically significant main effect $[\mathrm{f}(16.961,14.244)=9.207, \mathrm{p}<.05]$, loan and performance between the groups revealed that a statistically significant main effect $[f(8,1)=2.952, p<.05]$ and bonds and performance between the groups revealed that $a$ statistically significant main effect $[f(16,1)=4.998, p<.05]$. The study concluded that there is improvement in businesses of the customers who use Micro-Credit loans, loan repayment is a smooth process and Cash and deposit account at depository institutions, the short term loan, there is no special terms granted, no, special terms occasionally granted and term frequently granted, capital provided by the owners or shareholders of the enterprise are credit worthiness that is your track record of repaying past debts.
\end{abstract}

Keywords: credit facilities, Smes, Financial Performance

\section{INTRODUCTION}

Among the secrets of economic prosperity are innovation and competition, which is driven by the growth and survival of small businesses. For this reason, governments have designed policies and introduced incentives all of which are geared towards creating enabling environment for small and medium scale enterprises. SME in any country is very crucial for the creation of jobs, foreign exchange earnings, poverty reduction, wealth creation, equitable distribution of income and bridging the inequality gap.

Finance or credit is an essential input used in production as well as an enabler of the efficiency of other production inputs (Adebisi, Alaneme \& Ofuani, 2015). Credit is considered as very vital in every sphere of business. The United Nations Commission on International Trade Law (UNCITRAL), in its Legislative Guide on Secured Transactions, emphasizes the importance the international community places on secured credit; and stated that "all businesses, whether engaged in mining, lumbering, agriculture, manufacturing, distributing, providing services or retailing, require working capital to operate, to grow and to compete successfully in the marketplace" (World Bank, 2013). It is well established that one of the most effective means of providing working capital to commercial enterprises is through secured credit. Credit facilities 
are required by all classes of business organizations whether big, small, medium or micro operators. The distinguishing factor is the amount required and the application procedure or collaterals required for such credits. Levy in Ahiawodzi and Adade (2012) found that there is limited access to financial resources available to smaller enterprises compared to larger organizations and the consequences for their growth and development. Accessing credit has been identified as a key element for any business organization to be productive, compete, create jobs, help in poverty alleviation especially in developing nations and generally succeed. Getting credit has been rated as one of the key indicators for determining how easy or otherwise doing business in an economy can be.

\section{LITERATURE REVIEW}

Aguwamba and Ekienabor (2017) investigates bank lending and its impact on small-scale enterprises in Nigeria. The main issues in this paper relate to understanding the effects and impact of bank lending on small-scale enterprises. In order to analyse the data, econometric methods was used. The econometric regression model of ordinary least square was applied in evaluating the impact of bank lending on small-scale enterprises. The model revealed a positive impact of bank lending on small-scale enterprises. Some recommendations were made therein that measures be taken to create a pool of long-term funds to enable long tenor lending. In addition, measures should be taken to influence the regime of interest rate downward, ease loan documentation process and requirements, create additional inducement to boost lending to SMEs and augment monitoring of funds disbursed under the CBN intervention schemes.

Adebiyi, Banjo and Regin (2017) examined the impact of finance on the performance of small and medium enterprises in Lagos State. The research design adopted for this study is survey research design. Data analysis and hypotheses test from 250 SME owners and operators using Pearson correlation and regression analysis indicate that, there is a relationship between SME finance and business performance. Limited information on loan qualification criteria and high interest rate mostly pose challenge to SMEs in their quest to access finance. Results also show there is significant relationship between financial management practices and the performance of SMEs. Sequel to findings of the study, it is recommended that government Flexible arrangements should be put in place for SMEs in Lagos State to enable them access fund. Government should find way to encourage financial institution to lend to SMEs by providing guarantees, interest rate subsidies and other incentives.

Yusuf, Amao and Olawale (2014)examined the effects of micro credit on small scale enterprises in Osun State, Nigeria. Descriptive statistics and econometrics (regression analysis) were employed as tools for the analysis. Results showed that out of the 120 respondents that were sampled, 105 were credit users. The average age of the respondents was 40years and majority was female (about 61 percent). About 85 percent of the respondents were married with an average family size of 6 . A very few number of the respondents had tertiary education. The study also revealed that the average monthly income of the respondents that were engaged in farming was $\mathrm{N} 11,000$, that of artisan was $\mathrm{N} 19,500$ and that of trader was $\mathrm{N} 25,138.9$. The average loan sourced by Artisan was N24, 000 that of trader was N28, 000 and that of farmer was N4, 000. The average loan to all respondents was N282, 000. The regression analysis revealed that loan repayment period, family size and years in business were the key determinants of business turn over. On the other hand, volume of credit available to respondents is affected by repayment period, number of sources and interest on loan. 
Ikpor, Bernard and Obaji, (2017) There has not been unanimity on the effect of small and medium scale enterprises lending on economic growth in Nigeria. It is based on this, the study employed time series data from 1992 to 2013 to examine the impact of small and medium scale enterprises (SMEs) lending on economic growth in Nigeria using Augmented DickeyFuller (ADF) unit root test, Johansen cointegration test and vector error correction model techniques. The unit test results indicated that all the variables were non stationary at level but became stationary after first difference. The Johansen cointegration test showed evidence of long run relationship between small and medium scale enterprises lending and economic growth. The vector error correction model results revealed that lending to small and medium scale enterprises leads to economic growth in Nigeria. Also, the study found that bank lending rate does not impact on SMEs lending in Nigeria. The implication of these results is that lending to small and medium scale enterprises is crucial to the growth of Nigerian economy. The policy recommendation is that SMEs should be redefined in order to have greater access to fund, lowering of bank lending rate from the prevailing rate; stringent collateral security requirement should be relaxed to increase SMEs access to formal financial institutions, and encouragement of financial institutions to lend to SMEs by providing guarantees, interest rate subsidies. These will enhance credit availability to SMEs which will boost their productivity.

Ubesie, Onuaguluchi and Mbah (2017) ascertained the effect of deposit money banks' credit on small and medium scale enterprises growth in Nigeria. A lot of authors blamed lack of small and medium scale enterprises growth on non-availability and lack of access to finance while some others blame the same problem on managerial competency. Specifically, this study ascertains the effect of deposit money banks' credit to small and medium enterprises, credit to private sector and interest rate on small and medium scale enterprises growth in Nigeria. An ex-post facto research design which employed secondary data sourced from Central Bank of Nigeria (CBN) Statistical Bulletin 2015 and National bureau of statistics (NBS) for the period 1986 - 2015 was adopted. The ordinary least square regression method was used in the analysis of the data after conducting a stationarity test on the variables. The study finds out that deposit money banks 'credit to small and medium scale enterprises has no significant effect on small and medium scale enterprises growth in Nigeria. Again, the result indicates that deposit money banks' credit to private sector has significant effect on small and medium scale enterprises growth in Nigeria. The result also indicates that bank interest rate has serious significant effect on small and medium scale enterprises in Nigeria. To this effect, deposit money banks' management should see economic development as a priority by extending more credit to the private sector which are driven by small and medium scale enterprises.

Okafor, Ugochukwu and Chijindu (2016) investigated the impact of Small and Medium-sized Enterprises (SMEs) on the growth of the Nigerian economy for the period of 1986-2014. The study which is an ex-postfacto research employed data generated from Central Bank of Nigeria (CBN) statistical bulletin and Ordinary Least Square (OLS) method of estimation were employed in the data analysis. The result of the Augmented Dickey Fuller (ADF) test shows that all the variables are integrated of the same order one I (1). The result of the Johansen cointegration test indicates that there is a long run relationship between SMEs, Oil revenue (OILR), Inflation (INFRT) and economic growth in Nigeria. The result of the short run dynamic model as shown by the coefficient of Error Correction Model (ECM) reveals that the speed of adjustment from short run disequilibrium to long run equilibrium is about $42.83 \%$. The result of the OLS multiple regression analysis showed that SME, OILR, INFRT has a positive and significant impact on the growth of the Nigerian economy in the short run, while in the long run the result showed that SMEs has a positive but insignificant impact on the growth of the Nigerian economy. The study therefore suggested that polices that will increase the budgetary allocation to the sector should be adopted by the government as well as the introduction of a 
similar credit guarantee scheme like what is obtainable in the agricultural sector. Banks should also increase concessional (low interest rate) credit grant to this sector of the economy as they has the capacity to stimulate and drive the economy in the long run.

Ayuba and Zabairu (2015) examined the impact of banking sector credit on the growth of small and medium enterprises in Nigeria. The main objective of the study is to investigate whether banking sector credit has significant impact on the growth of small and medium enterprises in Nigeria. As part of the methodology, annual data between 1985 and 2010 was collected and used in the study while descriptive statistics, correlation matrix and error correction model was used to test the formulated hypotheses which reveals that banking sector credit has significant impact on the growth of small and medium enterprises in Nigeria as it has positive impact on some major macro-economic variables of growth such as inflation, exchange rate, trade debts etc. The study however, recommends that financial lending institutions (Monetary Authorities) should relax the stringent conditions associated with credit facility in the funding of SMEs in the country so as to encourage easy accessibility of loans which will help in improving SME's financing and performance.

Afolabi (2013) the issue of sustainable growth and development has been a growing concern for policy makers and researcher in developing countries such as Nigeria. One of the problems faced by Small and Medium Enterprises (SMEs) operators is that government does not give chance or consider them when making policy in which priority is given to large organizations. This makes financing the main constraining factor to SMEs growth and hinders their potentials for enhancing economic growth in Nigeria. Thus, constitute the focus of this study. On the basis of the identified issue and existence of few quantitative empirical studies in this regards, the study investigated the effect of SMEs financing on economic growth in Nigeria between 1980 and 2010. The study employed Ordinary Least Square (OLS) method to estimate the multiple regression model. The estimated model results revealed that SMEs output proxy by wholesale and retail trade output as a component of gross domestic product, commercial banks' credit to SMEs and exchange rate of naira vis-à-vis U.S dollar exert positive influence on economic development proxy real gross domestic product while lending rate is found to exert negative effects on economic growth. In terms of partial significance and using t-statistic as a test of evaluation, SMEs output and commercial banks' credit to SMEs were found to be significant factors enhancing economic growth in Nigeria at $5 \%$ critical level. Therefore, emanating from the findings, the study proffered that the central authority should create an enabling environment for SME development.

\section{Population of the Study}

\section{METHODS}

The population of the study comprised 1704 SMEs operators from 16 local government areas in Ekiti State Nigeria.

\section{Sampling Technique and Sample Size}

The stratified sampling technique was used to select the sample size from the captive population. Lists of registered small and medium enterprises were obtained from the Ministry of Commerce, Industries and Cooperatives, Ado-Ekiti, Ekiti State. Taro model was used to arrive at the sample size for the study. The total sample size for the study was 356.

\section{Data Collection}

The instrument for data collection was a questionnaire adapted by the researcher. The reliability coefficient of the instrument is 0.72 . The questionnaire consists of four sections. 
Section A sought personal data of the respondents such as gender, age, training qualification and rank. Section B shall be a 4-point Likert type scale consisting of 6 items. Each item had four response options ranging from strongly Agree (SA), Agree (A), Undecided (U), Disagree (D), and Strongly Disagree (SD). The respondents were required to indicate the extent of their agreement or disagreement with each item by ticking an option against each item.

\section{Method of Data Analysis}

To achieve the set objectives of the study inferential statistics was employed through the use of ANCOVA multiple regressions.

\section{Interest loan and performance}

\section{RESULTS}

Table 4.2: ANCOVA Results of Interest loan and performance Tests of Between-Subjects Effects

Dependent Variable: Performance

\begin{tabular}{|l|c|c|c|c|c|}
\hline Source & $\begin{array}{c}\text { Type III Sum } \\
\text { of Squares }\end{array}$ & Df & Mean Square & F & Sig. \\
\hline Corrected & $135.685 \mathrm{a}$ & 8 & 16.961 & 10.963 & .000 \\
Model & 841.738 & 1 & 841.738 & 544.106 & .000 \\
Intercept & 56.976 & 4 & 14.244 & 9.207 & .000 \\
Interest loan & 106.396 & 4 & 26.599 & 17.194 & .000 \\
Loan & 474.932 & 307 & 1.547 & & \\
repayment & 3521.000 & 316 & & & \\
Error & 610.617 & 315 & & & \\
Total & Corrected Total & & & & \\
\hline
\end{tabular}

a. $\mathrm{R}$ Squared $=.222$ (Adjusted R Squared $=.202$ )

The one-way ANCOVA of interest loan and performance between the groups revealed that a statistically significant main effect $[f(16.961,14.244)=9.207, \mathrm{p}<.05]$ indicating that not all two groups of interest loan uses resulted in the same performance.This implies that there is improvement in businesses of the customers who use Micro-Credit loans.

Loan repayment and performance between the groups revealed that a statistically significant main effect $[f(16.961,26.599)=17.194, \mathrm{p}<.05]$ indicating that not all two groups of interest loan uses resulted in the same performance. This implies that loan repayment is a smooth process and Cash and deposit account at depository institutions. 


\section{Trade credit and performance}

Table 4.4: ANCOVA Results of Trade credit and performance Tests of Between-Subjects Effects

Dependent Variable: Performance

\begin{tabular}{|l|c|c|c|c|c|}
\hline Source & $\begin{array}{c}\text { Type III Sum } \\
\text { of Squares }\end{array}$ & Df & Mean Square & F & Sig. \\
\hline Corrected & $130.461^{\mathrm{a}}$ & 8 & 16.308 & 10.427 & .000 \\
Model & 330.363 & 1 & 330.363 & 211.226 & .000 \\
Intercept & 18.467 & 4 & 4.617 & 2.952 & .020 \\
Short loan & 106.545 & 4 & 26.636 & 17.031 & .000 \\
Crowdfund & 480.156 & 307 & 1.564 & & \\
Error & 3521.000 & 316 & & & \\
Total & 610.617 & 315 & & & \\
Corrected Total & 615 & & \\
\hline
\end{tabular}

a. $\mathrm{R}$ Squared $=.214$ (Adjusted R Squared $=.193$ )

The one-way ANCOVA of short term loan and performance between the groups revealed that a statistically significant main effect $[f(8,1)=2.952, \mathrm{p}<.05]$ indicating that not all two groups of short term loan use resulted in the same performance. This implies that there is improvement in businesses of the customers who use Micro-Credit loans. This implies that for the short term loan, there is no special terms granted, no, special terms occasionally granted and term frequently granted.

Crowdfunding and performance between the groups revealed that a statistically significant main effect $[f(8,1)=17.031, \mathrm{p}<.05]$ indicating that not all two groups of crowdfunding uses resulted in the same performance. This implies that capital provided by the owners or shareholders of the enterprise and credit worthiness that is your track record of repaying past debts.

\section{Asset Financing and performance}

Table 4.5: ANCOVA Results ofAsset Financing and performance Tests of Between-Subjects Effects

Dependent Variable: Performance

\begin{tabular}{|l|c|c|c|c|c|}
\hline Source & $\begin{array}{c}\text { Type III Sum } \\
\text { of Squares }\end{array}$ & Df & Mean Square & F & Sig. \\
\hline Corrected & $319.540^{\mathrm{a}}$ & 16 & 19.971 & 20.515 & .000 \\
Model & 295.031 & 1 & 295.031 & 303.062 & .000 \\
Intercept & 19.462 & 4 & 4.866 & 4.998 & .001 \\
Bonds & 11.733 & 4 & 2.933 & 3.013 & .018 \\
Stock & 17.341 & 4 & 4.335 & 4.453 & .002 \\
Bank Deposits & 203.195 & 4 & 50.799 & 52.181 & .000 \\
Loans & 291.077 & 299 & .974 & & \\
Error & 3521.000 & 316 & & & \\
Total & 610.617 & 315 & & & \\
Corrected Total & 615.615 & & & \\
\hline
\end{tabular}

a. R Squared $=.523$ (Adjusted R Squared $=.498$ )

The one-way ANCOVA of bonds and performance between the groups revealed that a statistically significant main effect $[f(16,1)=4.998, \mathrm{p}<.05]$ indicating that not all two groups of short term loan use resulted in the same performance. This implies that the asset financing 
have indemnities family trust and individuals, spouses personally indemnify to procure surety bonds.

Stock and performance between the groups revealed that a statistically significant main effect $[f(16,1)=3.013, \mathrm{p}<.01]$ indicating that not all two groups of stock uses resulted in the same performance. This implies that internal feeling affects your decision about purchasing a stock and to follow group behaviour in risky financial products.

Bank deposits and performance between the groups revealed that a statistically significant main effect $[f(16,1)=4.453, \mathrm{p}<.05]$ indicating that not all two groups of bank deposits uses resulted in the same performance. This implies that SMS alerts about specific information to the bank services / new products and Reduction in balance without cash payment.

Loans and performance between the groups revealed that a statistically significant main effect $[f(16,1)=52.181, \mathrm{p}<.05]$ indicating that not all two groups of loans uses resulted in the same performance. This implies that satisfied with the rate of interest of bank, attracting, retaining customers and customer counseling.

\section{CONCLUSION AND RECOMMENDATION}

The study concluded that there is improvement in businesses of the customers who use MicroCredit loans, loan repayment is a smooth process and Cash and deposit account at depository institutions, the short term loan, there is no special terms granted, no, special terms occasionally granted and term frequently granted, capital provided by the owners or shareholders of the enterprise are credit worthiness that is your track record of repaying past debts.

\section{Recommendation}

Based on the conclusion, the study recommended that the Nigeria deposit money banks should maintain tight monitoring of borrowers in their use of loans borrowed so as to reduce their risk of loss on account of loans borrowed being used for unprofitable uses by borrowers.

The Nigeria government should increase provision of infrastructural facilities such as electricity, good roads, effective transport, market for locally produce goods, and training and awareness programs in order to reduce the operating costs of SMEs and by so doing Nigeria SME risks of operations will be reduced and enable SMEs to contribute positively to Nigeria's economic growth.

\section{References}

Abereijo, I.O. \& Fayomi, A.0. (2005). Innovative approach to SME financing in Nigeria: A review of small and medium industries equity investment scheme (SMIEs).J. Soc. Sci., 11(3), 219-227.

Abor, J. (2007). Corporate governance and financing decisions of Ghanaian listed firms, Corporate Governance.International Journal of Business in Society, 7(1), 83-92.

Adebusuyi, B.S. (1997). Performance evaluation of small-medium enterprises (SMEs) in Nigeria. Central Bank of Nigeria Bullion, 21(4), 46-52.

Afolabi, M.O. (2013). Growth effect of small and medium enterprises (SMEs) financing in Nigeria.Journal of Macroecoomics Review, 3(1), 193-205.

Akingunola, R.O. (2011). Small and medium scale enterprises and economic growth in Nigeria: An assessment of financing options.Pakistan Journal of Business and Economic Review, 2(1), 78-97.

Aremu, M.A. \& Adeyemi, S.L. (2011). Small and medium scale enterprises as a survival strategy for employment generation in Nigeria.Journal of Sustainable Development, 4(1), 200-206. 
Ayuba, B. \& Zubairu, M. (2015). Impact of banking sector credit on the growth of small and medium enterprises (SME's) in Nigeria.Journal of Resources Development and management, 15, 1-9.

Beck, T. (2017). Financing constraints of SMEs in developing countries: Evidence, determinants and solutions. Journal of International Money and Finance, 31(2), 401-441. International Journal of Development and Sustainability, 6(10), 1400-1417.

Beck, T. \& Demirguc-Kunt, A. (2006). Small and medium-size enterprises. Access to finance as Growth Constraint.Journal of Banking and Finance, 30(11), 2931-2943.

Beck, T., Demirguc-Kunt, A. and Levine, R. (2005). SMEs, growth, and poverty: cross-country evidence", Journal of Economic Growth, 10(3), 199-229.

Berger, A.N. \& Udell, G.F. (1998). The economics of small business finance: The roles of private equity and debt markets in the financial growth cycle", Journal of Banking and Finance, Vol. 22 No. 6, pp. 613-673.

Binks, M.R., Ennew, C.T. and Reed, G.V. (1992), "Information Asymmetries and the Provision of Finance to Small Firms", International Small Business Journal, Vol. 11 No. 1, pp. 35-46.

Brian, G.F. and Shingirayi, M. (2014), "Challenges faced by small to medium scale enterprises: A case study of Chitungwiza, Zimbabwe", Greener Journal of Business and Management Studies, Vol. 4 No. 4, pp. 103-107.

Central Bank of Nigeria (2006), Statistical Bulletin, Central Bank of Nigeria, Abuja.

Central Bank of Nigeria (2015), Statistical Bulletin, Central Bank of Nigeria, Abuja.

Chinweuba, E.T. and Sunday, O.C. (2015), "Quantitative analysis of the impact of small and medium scale enterprises on the growth of Nigerian economy (1993-2011)", International Journal of Development and Emerging Economics, Vol. 3 No.1, pp. 26-38.

Chughtai, M.W. (2014), "Impact of small and medium enterprises on economic growth: Evidence from Pakistan", Standard Research Journal of Business Management, Vol. 2 No. 2, pp. 19-24.

Edet, B.N., Anoka, A.F. and Antakikam, A.E. (2014), "Bank lending, macro-policy variables and the growth of small scale industries in Nigeria", International Journal of Business and Social Science, Vol. 5 No. 9, pp. 284-290.

Ekpeyong, D.B. and Nyong, M.O. (1992), "Small and medium scale enterprises development in

Nigeria", Seminar paper on economic policy research for policy design and management in Nigeria", NCEMA /AEPS, 24-25 April, Nigeria.

Floyd, D. and McManus, J. (2005), "The role of SMEs in improving the competitive position of the European Union", European Business Review, Vol. 17 No. 2, pp. 144-150.

Ihua, U.B. (2009), "SMEs key failure-factors: a comparison between the United Kingdom and Nigeria", Journal of Social Science, Vol. 18 No 3, pp. 199-207.

Iloh, J. and Chioke, N. (2015), "Commercial bank credit availability to small and medium scale enterprises (SMEs) in Nigeria", paper presented at 3rd International Conference on Business, Law and Corporate Social Responsibility (ICBLCSR'15), 5 May-6 May, Bali, Indonesia, available at: http://icehm.org/upload/6920ED0515051.pdf (Accessed 30 November 2016).

King, R.G. and Levine, R. (1993), "Finance and growth: Schumpeter might be right", Quarterly Journal of Economics, Vol. 108 No. 3, pp. 717- 738.

Makorere, R.F. (2014), "Factors affecting loan repayment behaviour in Tanzania: Empirical evidence from Dar es Salaam and Morogoro regions", International Journal of Development and Sustainability, Vol. 3 No. 3, pp 481-492.

Kadiri, I. B. (2012) Small and Medium Scale Enterprises and Employment Generation in Nigeria: The Role of Finance. Kuwait Chapter of Arabian Journal of Business and Management Review, 1(9), 79-93.

Iloh, J. \& Chioke, N. (2015). Commercial Bank Credit Availability to Small and Medium Scale

Enterprises (SMEs) in Nigeria. rd International Conference on Business, Law and Corporate Social Responsibility (ICBLCSR'15) May 5-6, 100-106.

Owolabi, O. A. \& Nasiru, A. (2017). Deposit money bank credit to small and medium enterprises, socio-economic performance and economic growth in Nigeria. International Journal of Development and Sustainability, 6(10), 1400-1417.

Afolabi, M. O. (2013). Growth effect of Small and Medium Enterprises (SMEs) Financing in Nigeria. Journal of African Macroeconomic Review, 3(1), 
Ayuba, B. \& Zubairu, M. (2015). Impact of Banking Sector Credit on the Growth of Small and Medium Enterprises (SME's) in Nigeria. Journal of Resources Development and Management, 15, 1-9.

Okafor, I. G., Ugochukwu, U.S. \& Chijindu, E.H. (2016). Impact of Small And Medium-Sized Enterprise On The Growth Of The Nigerian Economy: A Co-Integration Approach. International Journal of Economics, Commerce and Managemen, 4(6), 678-692.

Ubesie, M. C., Onuaguluchi, I. F., \& Mbah, A. M. (2017).Effect of Deposit Money Banks Credit on Small and Medium Scale Enterprises Growth in Nigeria. International Journal of Finance and Accounting, 6(5), 117-132.

Ikpor, R. N., Bernard, E. \& Obaji, S. I. (2017). Bank Lending to Small and Medium Scale Enterprises and Its Implication on Economic Growth in Nigeria. IOSR Journal of Humanities and Social Science (IOSR-JHSS) Volume 22(12), 14-28.

Yusuf S.A, Amao J.O., \& Olawale O.T. (2014).Effects of Microcredit on Small Scale Enterprises in Osun State, Nigeria. American International Journal of Contemporary Research, 4(6), 190- 200.

Adebiyi1, A.J., Banjo, H.A. Regin, O.0. (2017). Performance of Small and Medium Enterprises in Lagos State: The Implications of Finance. Acta Universitatis Danubius, 13(5), 72-83.

Aguwamba, S. M.\& Ekienabor, E. E. (2017). Bank Lending and its Impact on Small Scale Enterprises in Nigeria. Imperial Journal of Interdisciplinary Research (IJIR), 3(3), 58-66. 